\title{
WINTER DISTRIBUTION, DENSITY AND SIZE OF MESODESMA MACTROIDES (BIVALVIA, MACTRACEA) IN MONTE HERMOSO BEACH (ARGENTINA)
}

\author{
Sandra Marcela Fiori*, Nestor J. Cazzaniga \& Alejandra L. Estebenet \\ Universidad Nacional del Sur \\ Departamento de Biología, Bioquímica y Farmacia \\ (San Juan 670 (8000) Bahía Blanca, Argentina)
}

\begin{abstract}
A B S T R A C T
The yellow clam Mesodesma mactroides (Deshayes, 1854) is a seasonal migrant that moves in spring to the sandy upper intertidal level. In this paper we analyze the spatial distribution of density and mean shell size of the yellow clam population in Monte Hermoso beach (Argentina) in winter 1995, i.e., three months before the mass mortality occurred in November 1995. Sampling covered $32 \mathrm{~km}$ of beach, with a regular design of 22 transects. The major environmental gradient in the beach was determined using principal component analysis (PCA) on the correlation matrix of the environmental data (beach morphology, slope, and sand granulometry). Correlation analysis was used to assess the relationship between the score of a site (transect) on the first and second principal component, and clam mean density and mean shell size. Most of the beach seems to be habitable for clams, their spatial heterogeneity not having been explained by the measured variables since, although the first axis of the PCA has demonstrated an E-W physical gradient, clam density was not in correlation with it. Density was maximum near the piers, even though these are points with high tourist activity. It seems that non-extractive touristic activities do not affect population density but rather mean shell size, probably due to reduction of growth rates. The abundance of the winter population, as compared with the assessment done after the mass mortality of November, strongly suggests that a great part of the population was overwintering in the intertidal fringe.
\end{abstract}

\section{RESUMO}

O molusco Mesodesma mactroides (Deshayes, 1854) é uma espécie migrante sazonal que na primavera move-se para o nível entremarés superior da praia. Neste estudo, analisamos a distribuição espacial da densidade e o tamanho médio da população do bivalve na praia de Monte Hermoso (Argentina) no inverno de 1995, i. é, três meses antes da mortalidade massiva desses moluscos, acontecida em novembro de 1995. A amostragem cobriu $32 \mathrm{~km}$ da praia, utilizando-se 22 transectos distribuídos regularmente. O gradiente ambiental principal na praia foi determinado mediante Análise de Componentes Principais (ACP) a partir da matriz de correlação dos dados ambientais (morfologia e declividade da praia, e granulometria da areia). A análise da correlação foi utilizada para avaliar a relação entre o escore de um local (transecto) no primeiro e segundo componentes principais, a densidade média dos moluscos e tamanho médio da concha. A maior parte da praia parece ser um habitat apropriado para esses moluscos e sua heterogeneidade espacial não foi explicada pelas variáveis medidas, uma vez que, embora o primeiro eixo da PCA tenha demonstrado um gradiente físico no sentido L-O, a densidade dos moluscos não apresentou correlação com o mesmo. A densidade apresentou o máximo valor próximo aos molhes, pontos de grande fluxo turístico, atividade esta que quando não acarreta coleta de moluscos parece não afetar a densidade da população, mas sim o tamanho médio da concha através de uma redução da taxa de crescimento. A abundância da população no inverno, em comparação com a avaliação feita após a mortalidade em massa de novembro, sugere que a maior parte da população passa o inverno na faixa entremarés.

Descriptors: Sandy beach, Tourism effects, Shell size, Abundance, Overwintering, Yellow clam. Descritores: Praia arenosa, Efeitos do turismo, Tamanho da concha, Abundância, Área de invernagem, Marisco branco.

\section{INTRODUCTION}

Yellow clam, Mesodesma mactroides (Deshayes, 1854), is a main component in intertidal communities of dissipative sandy beaches along the South Western Atlantic coasts (Fig. 1). Due to sudden depletions occurred all over its geographic range

(*) Fax: +54 291 452129. E-mail: sfiori@criba.edu.ar
(Santos Bay in southern Brazil, to southern Buenos Aires province, Argentina) from 1993 to 1995, the species is presently at risk, probably with a "critically endangered" status (IUCN, 1994; Fiori \& Cazzaniga, 1999). Even though the species is legally protected in Argentina, clams are extracted for food and bait, tourist pressure being a possible factor affecting the recovery of the depleted populations (Bastida et al., 1991). 


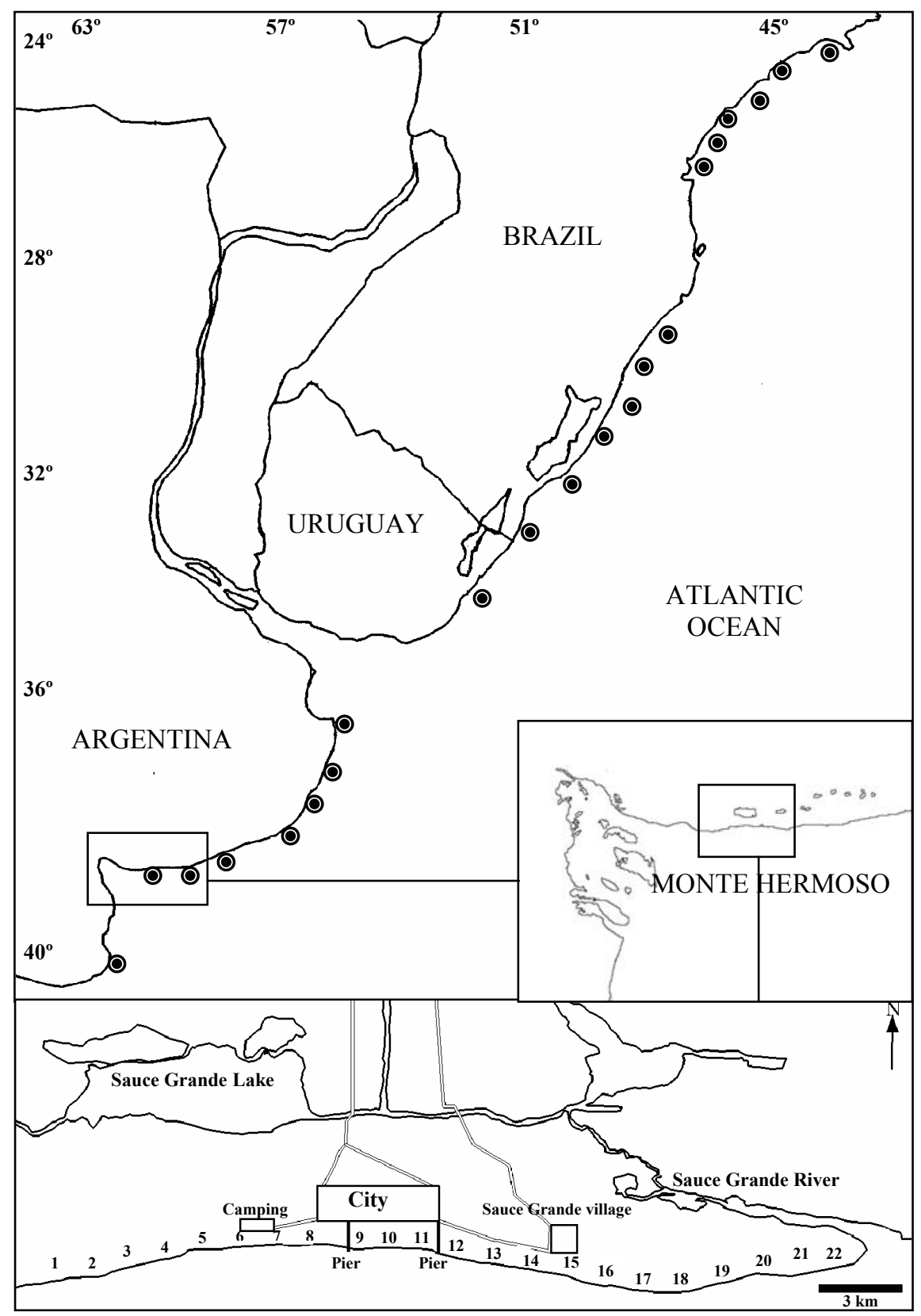

Fig. 1. Geographic distribution of Mesodesma mactroides (adapted from Olivier et al., 1971), and a map of Monte Hermoso beach showing the location of the 22 transects analyzed in this study.

Yellow clams thrive primarily in intertidal beaches with gentle slope, fine sand and heavy wave action (McLachlan et al., 1996). It is a seasonal migrant that massively moves from their winter location to the intertidal spring-summer position in October-November. Yellow clam population mostly overwinters below the low tide level (Coscarón, 1959; Olivier et al., 1971) although this assumption has not been supported with quantitative data. 
In this paper we aim to analyze the spatial density and mean shell size distribution of the yellow clam population in Monte Hermoso beach (Argentina), near the southernmost boundary of its distribution area. This locality was mentioned as a high-density clam site, the place where clams attain the maximum individual size in Argentina, and the point where the local people and tourist impact on clams was most evident (Olivier \& Penchaszadeh, 1968). Sampling was made in July-August 1995; therefore, this study gives a snapshot of population status during the wintertime previous to the massive mortality occurred in November 1995 in this locality (Fiori \& Cazzaniga, 1999).

\section{Study AREA}

Monte Hermoso ( $\left.38^{\circ} 59^{\prime} \mathrm{S} ; 61^{\circ} 41^{\prime} \mathrm{W}\right)$ is a 32 $\mathrm{km}$ long, exposed sandy beach on the southern coast of the Buenos Aires province (Fig. 1). It is a wide beach of destruction with E-W orientation, backed by a fringe of dunes. A well-developed trough-bar zone is interrupted by ledge of rocks in the west (Caló et al., 1995).

The tides are semidiurnal, with amplitudes of 1.25 to $3.63 \mathrm{~m}$ (Servicio de Hidrografía Naval, 1995). The most common kind of breakers are spread waves indicating dissipation conditions. The normal wave height varies from 0.3 to $0.6 \mathrm{~m}$, with periods of 6 to 7 seconds; waves can reach up to $1.80 \mathrm{~m}$ high, with shorter periods during storms (Caló et al., 1995). The mean annual air temperature for 1983-1985 was $14.9^{\circ} \mathrm{C}$ and the mean annual oscillation was $14^{\circ} \mathrm{C}$ (Piccolo et al., 1987).

Nowadays, the most important economic activity in Monte Hermoso town is tourism, which showed a tenfold increase during the period 19681995, with approximately 550000 people vacationing there each summer (Monte Hermoso County, Tourism Secretary, pers. comm.*). There is also some artisanal fishing and extraction of beach sand for construction. Two piers delimit the main bathing area ( $3 \mathrm{~km}$ long), from where coastal sand dunes were removed and many public and private service structures built. The area to the west of Monte Hermoso is generally less suitable for sports and bathing owing to the presence of rocky outcrops.

Even when the sandy beach extends all along, the number of tourists decreases towards the east of the eastern pier. A coastal road of about $11 \mathrm{~km}$ joins Monte Hermoso town with Sauce Grande village, beyond which there are neither roads nor services for visitors. Therefore, only a few fishermen and walkers visit the mouth of Sauce Grande River (Fig. 1).

(*) Monte Hermoso County, Tourism Secretary. Director Vicente Dimartino, 1995.

\section{Materials And Methods}

Sampling was made in July and August 1995 (winter), along intertidal transects perpendicular to the shoreline. Twenty-two transects were located at intervals of $1.5 \mathrm{~km}$ to cover the whole beach length (Fig. 1). The material contained in a quadrat of $50 \times 50$ $\mathrm{cm}$ was dug out up to $50 \mathrm{~cm}$ deep every $10 \mathrm{~m}$ along each transect, from the low level of shoreline $(0 \mathrm{~m})$ upwards to the point where no more clams appeared (3 to 9 parcels per transect). The material was sieved out using a $1 \mathrm{~cm}$ mesh, the retained clams being counted and measured.

One sand sample for granulometric analysis (a core $5 \mathrm{~cm}$ in diameter and $50 \mathrm{~cm}$ long) was taken from the lowest level of each transect across the shoreline (sand samples from transects 1, 2 and 4 are missing). Mechanical sieving was made with a series of ten Standard Tyler sieves with decreasing mesh size to obtain the proportion of the main sand fractions in the Wentworth scale (very coarse, coarse, medium, fine and very fine sand, mud). Mean grain size and standard deviation as a measure of sand sorting were calculated by the equations of Folk \& Ward (1957).

Morphology of the shore at each transect was recorded according to a three qualitative category system: (1) beach with trough and sandbar; (2) sandy flat beach; (3) intertidal outcrop. Beach slope was estimated for each transect with a clinometer.

The major environmental gradient in the beach was determined using principal component analysis (PCA) on the correlation matrix of the environmental data (beach morphology, slope, and coarse, medium, fine and very fine sand fractions; very coarse and mud fractions were excluded to avoid redundancy). Pearson's correlation was used to assess the relationship between the score of a site (transect) on the first and second principal component, and clam mean density and mean shell size.

\section{RESULTS}

Table 1 summarizes the results of the sand granulometric analysis and a sketch of the morphologic characteristics of the beach over the study area. The western area of Monte Hermoso beach (transects 3-10) has fine sands $(<0.25 \mathrm{~mm})$; while the eastern sector (transects 11-21) shows mostly medium sands $(<0.5 \mathrm{~mm})$, except for the area closest to the Sauce Grande River mouth (transect 22), where sand is fine. Sand sorting is generally moderate (standard deviation of sand grains between 0.50 and $0.71 \mathrm{~mm}$ ). Figure 2 and Table 2 show the results of the PCA performed on the physical variables characterizing transects along Monte Hermoso beach. Granulometric 
conditions are the main variables defining axis 1 , so transects with fine or very fine sand and rocky patches score higher on this axis. Transects with a high proportion of coarse sand and flat beach score, instead, higher on Axis 2.

Table 1. Sand granulometry, slope and beach morphology along Monte Hermoso beach. Transects were placed at intervals of $1.5 \mathrm{~km}$ from the western limit of Monte Hermoso County (transect 1) to the mouth of the Sauce Grande River (transect 22). Beach morphology codes: (1) beach with trough and sandbar; (2) sandy flat beach; (3) intertidal outcrop. No data were available for transect 1,2 and 4 .

\begin{tabular}{|c|c|c|c|c|}
\hline \multirow[t]{2}{*}{ Transect } & \multicolumn{2}{|c|}{ Sand grain $(\mathrm{mm})$} & \multirow{2}{*}{$\begin{array}{l}\text { Slope } \\
(\%)\end{array}$} & \multirow{2}{*}{$\begin{array}{c}\text { Beach } \\
\text { morphology }\end{array}$} \\
\hline & Mean & St. Deviation & & \\
\hline 3 & 0.23 & 0.62 & 2.5 & 1 \\
\hline 5 & 0.19 & 0.65 & 1 & 2 \\
\hline 6 & 0.18 & 0.69 & 1 & 3 \\
\hline 7 & 0.16 & 0.72 & 1 & 3 \\
\hline 8 & 0.23 & 0.62 & 2 & 3 \\
\hline 9 & 0.23 & 0.56 & 1.5 & 2 \\
\hline 10 & 0.22 & 0.62 & 1 & 2 \\
\hline 11 & 0.31 & 0.61 & 2 & 1 \\
\hline 12 & 0.26 & 0.61 & 2 & 1 \\
\hline 13 & 0.33 & 0.49 & 2 & 1 \\
\hline 14 & 0.30 & 0.69 & 2 & 1 \\
\hline 15 & 0.31 & 0.65 & 1.5 & 1 \\
\hline 16 & 0.27 & 0.66 & 2.5 & 1 \\
\hline 17 & 0.35 & 0.66 & 2 & 2 \\
\hline 18 & 0.31 & 0.64 & 2.5 & 1 \\
\hline 19 & 0.44 & 0.65 & 2 & 2 \\
\hline 20 & 0.41 & 0.54 & 2.5 & 2 \\
\hline 21 & 0.30 & 0.60 & 2 & 1 \\
\hline 22 & 0.22 & 0.60 & 4 & 1 \\
\hline
\end{tabular}

The clam bed occupied $25.5 \mathrm{~km}$, with a maximum variable width of $80 \mathrm{~m}$ on transect 9 , although more than $85 \%$ of the specimens collected over the whole area were within the first $30 \mathrm{~m}$ (Fig. 3). The mean width of the clam bed was estimated in $22.5 \mathrm{~m}$.

Few clams were collected on the west side of the area (transects 1 to 8 , with a maximum density of $30 \mathrm{clams} / \mathrm{m}^{2}$ ) because rocky patches cause an important shortage of suitable substratum for the species. In the rest of the beach (transects 9 to 22) the presence of $M$. mactroides was continuous, but heterogeneously distributed (Fig. 4). Correlation of yellow clam mean density of each transect with the corresponding scores on axes 1 and 2 of PCA gave non-significant values of $\mathrm{r}=-0.36$ (d.f. $=17 ; \mathrm{p}=0.13$ ) and $\mathrm{r}=0.04$, respectively.

Mean density of Mesodesma mactroides was 83.08 clams $/ \mathrm{m}^{2} \pm 13.12$ (standard error) over the studied area $(n=65)$, with maximum values of 440 clams $/ \mathrm{m}^{2}$ on transects 9 and 11 , i.e. near the piers delimiting the main bathing area. Population size over the whole intertidal bed (57.38 ha) was 47.67 million clams.

Figure 5 shows the mean shell length of Mesodesma mactroides on each transect, which were significantly different along the beach (ANOVA test, $\mathrm{F}=30.92 ;$ d.f. $=17,1329 ; \mathrm{p}=0.000)$, with a tendency to size increase towards the east. Correlation of mean shell size with the scores of transects on axis 1 of PCA was highly significant $(r=-0.69 ;$ d.f. $=15 ; p=0.002)$ but it was not significant with those on axis $2(\mathrm{r}=$ 0.005).

Correlation between shell size and density was not significant $(\mathrm{r}=0.12$; d.f. $=16 ; \mathrm{p}=0.65)$, so crowding effects on clam size can be discarded.

\section{DISCUSSION}

Most recent knowledge on Mesodesma mactroides has been gathered from microtidal beaches in Uruguay, with astronomic tides of only $0.5 \mathrm{~m}$ and fine to very fine sands (Defeo et al., 1986, 1992; Brazeiro \& Defeo, 1996). Monte Hermoso beach has instead a tide amplitude of $2.38 \mathrm{~m}$, with an intertidal zone of over $100 \mathrm{~m}$ of width, the foredunes lying approximately $300 \mathrm{~m}$ beyond the high water line. These scale differences may have an effect on the dynamics of the species.

Most locations in Monte Hermoso beach have well-developed trough-bar systems parallel to the coast, with medium sized sand grains. Habitat stability provided by the sandbars and their associated troughs depends on seasonally varying conditions. Their building and persistence are in correlation with the wave regime.

A preference for trough-bar sites was described in New Zealand for the toheroa clam, Paphies ventricosa (Mesodesmatidae), which is morphologically and ecologically similar to Mesodesma mactroides, and it was hypothesized that these habitats might provide some advantages related to the micro-slope, which is more prominent on the bars than in the rest of the beach profile. Bars can generate a zone where the waves strike harder and probably create more oxygenated microhabitats, with a higher abundance of phytoplankton (Rapson, 1952; 1954). 


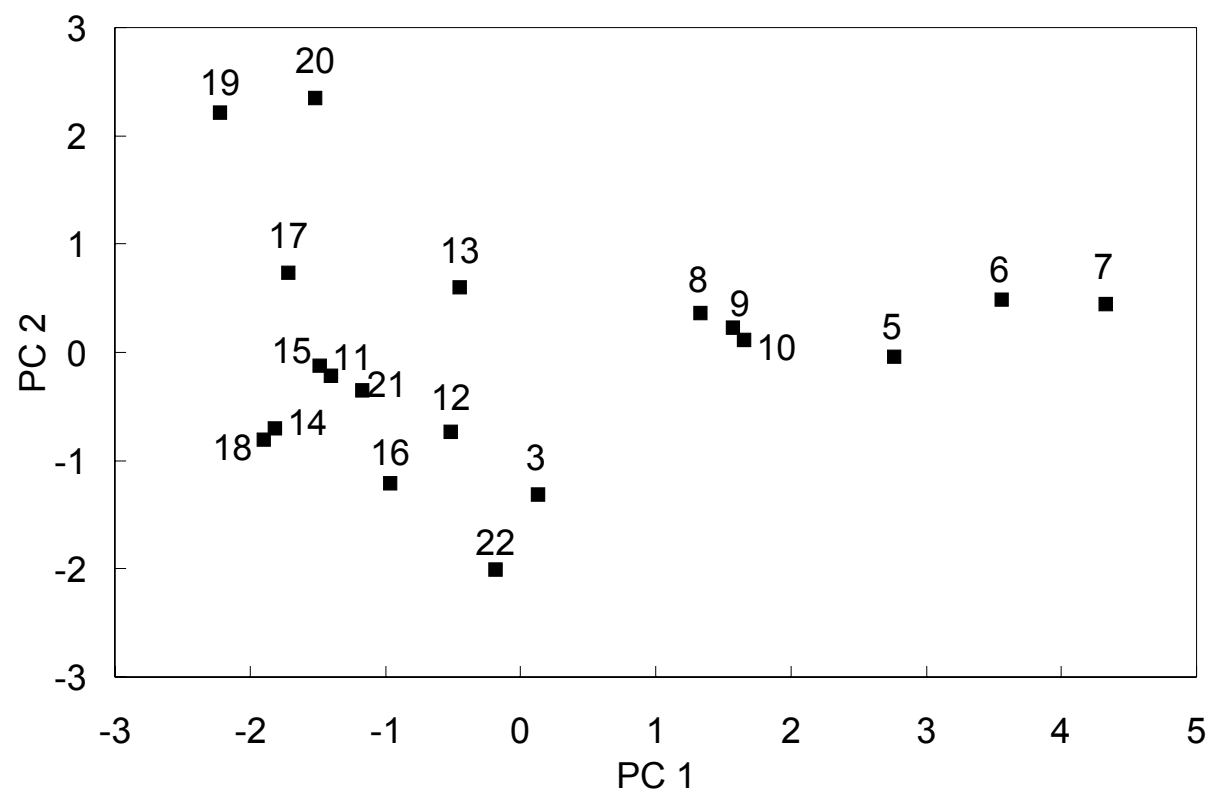

Fig. 2. Plot of sampling sites along Monte Hermoso beach, arranged on the two first Principal Component Axes (PCA on physical variables). Numbers identify transects to which sampling sites belong.

Table 2. Results of Principal Component Analysis of the transects along Monte Hermoso beach, based on a correlation matrix of physical variables.

\begin{tabular}{lccc}
\hline \hline \multicolumn{1}{c}{ PC } & $\mathbf{1}$ & $\mathbf{2}$ & $\mathbf{3}$ \\
\hline Eigenvalue & 3.69 & 1.11 & 0.81 \\
\% of variability & 0.61 & 0.18 & 0.13 \\
Cumulated \% & 0.61 & 0.80 & 0.93
\end{tabular}

Correlations between variables and principal factors

\begin{tabular}{lccc}
\multicolumn{1}{c}{ Variables } & PC 1 & PC 2 & PC 3 \\
Coarse sand & -0.57 & 0.72 & 0.37 \\
Medium sand & -0.86 & -0.15 & -0.44 \\
Fine sand & 0.93 & -0.33 & 0.09 \\
Very fine sand & 0.97 & -0.03 & 0.18 \\
Slope & -0.58 & -0.39 & 0.66 \\
Beach morphology & 0.70 & 0.55 & -0.07 \\
\hline
\end{tabular}




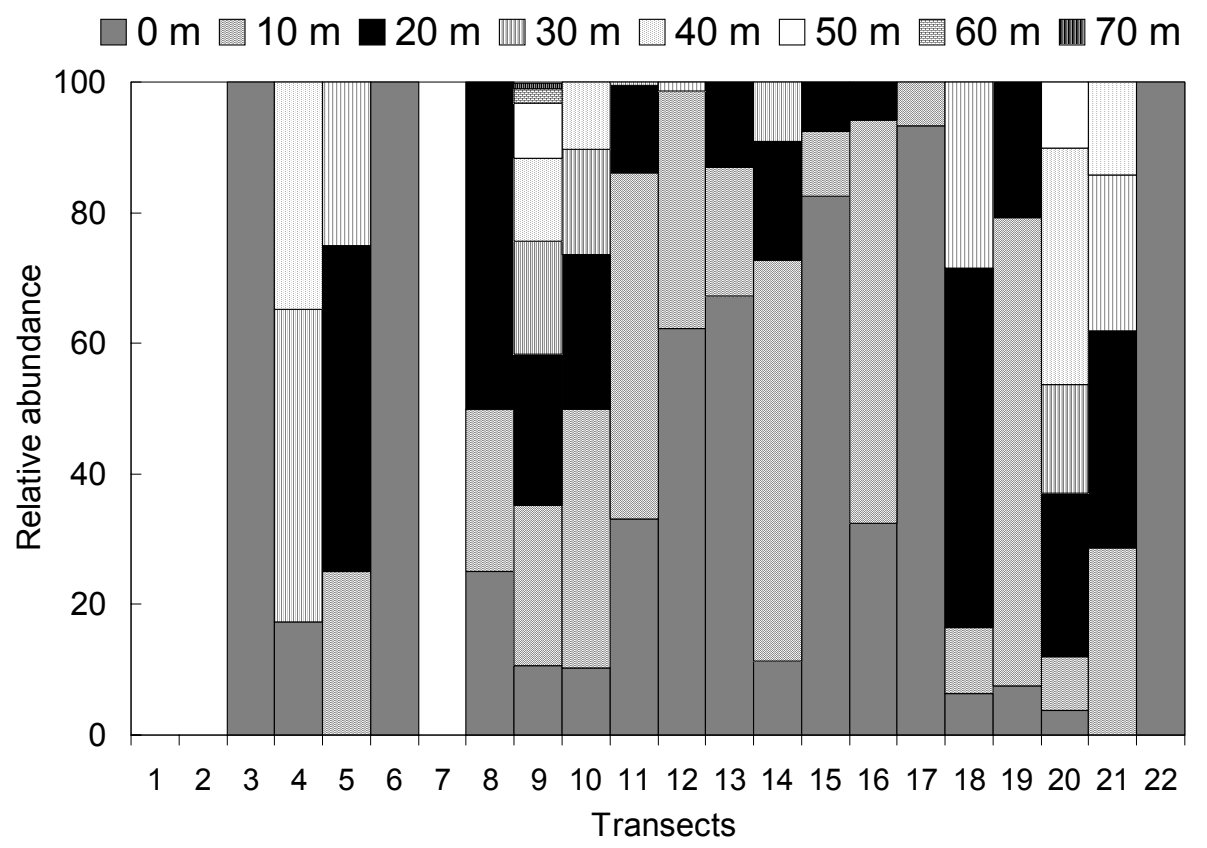

Fig. 3. Relative abundance of Mesodesma mactroides at different levels from the low tide line $(0$ meters) on each transect along Monte Hermoso beach.

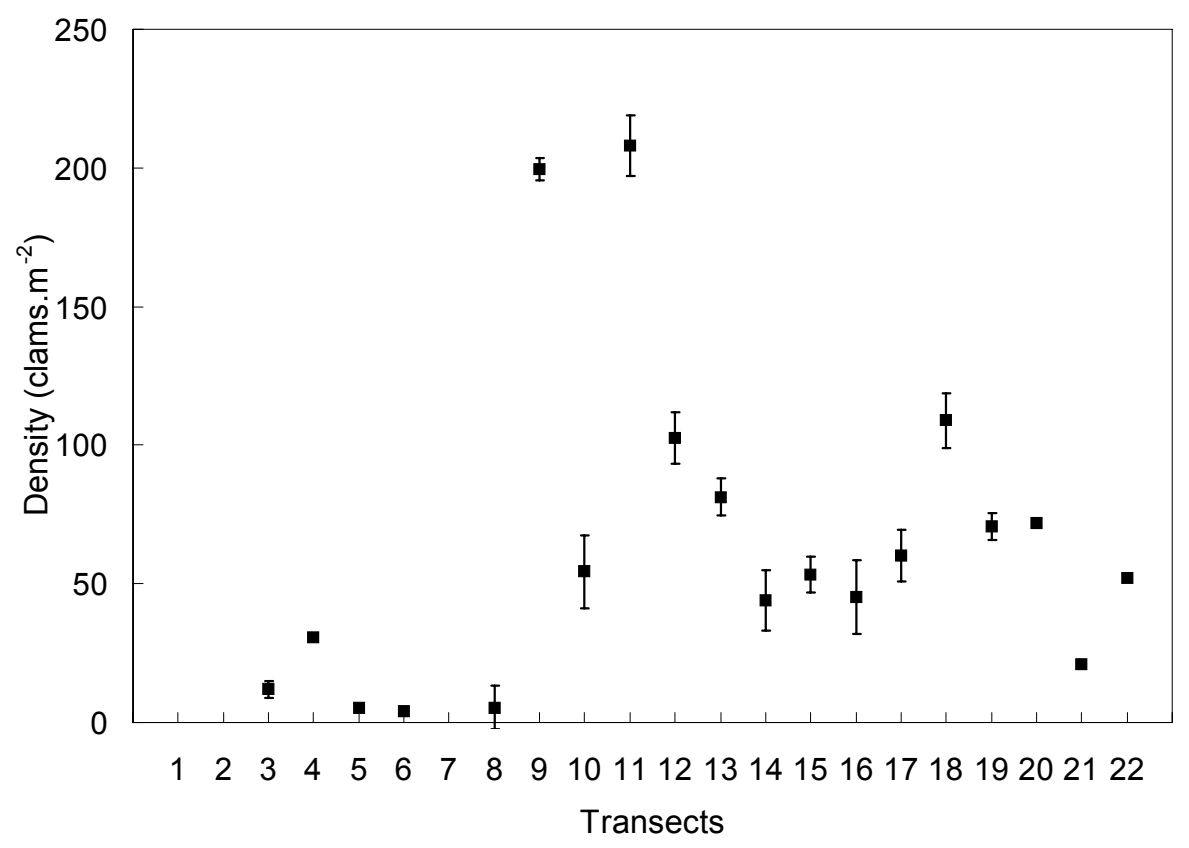

Fig. 4. Density of Mesodesma mactroides (individuals $/ \mathrm{m}^{2}$ ) on each transect along Monte Hermoso beach (Mean \pm Standard Error) 


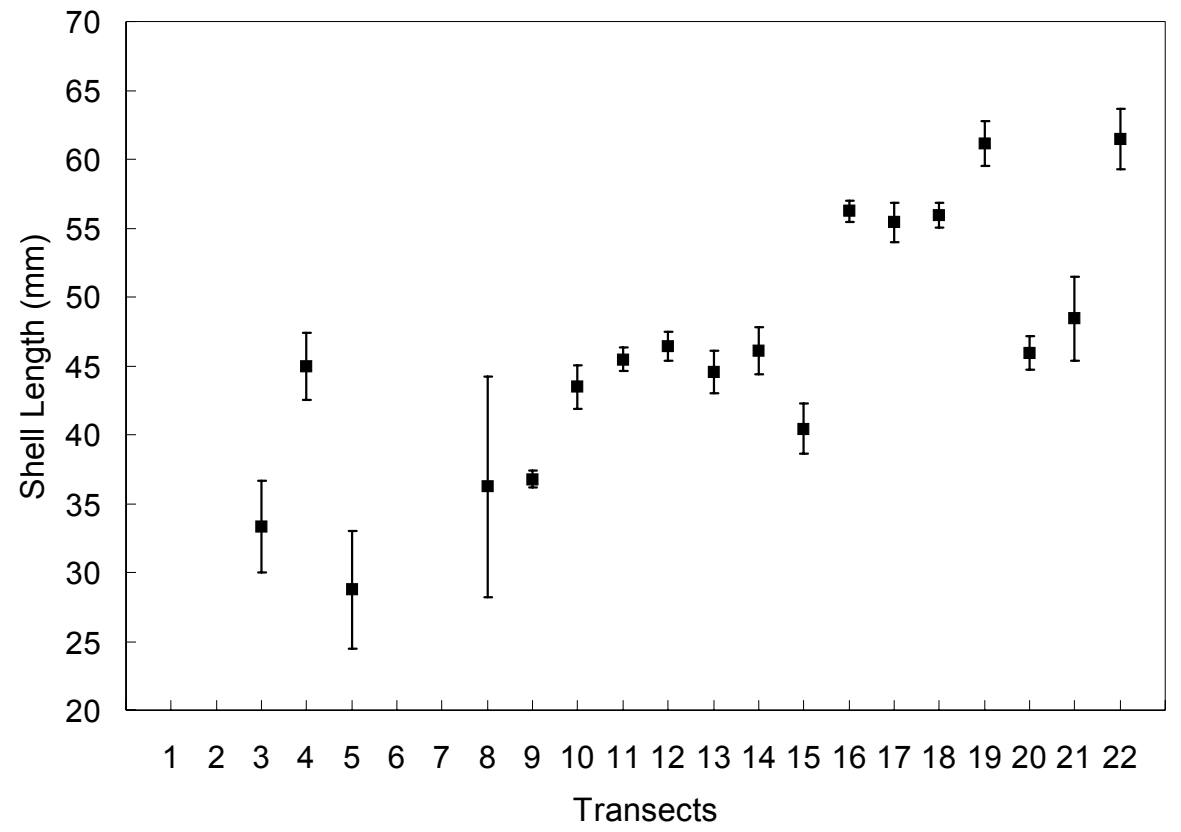

Fig. 5. Shell length of Mesodesma mactroides on each transect along Monte Hermoso beach (Mean \pm Standard Error).

However, the absence of a bar was not a limiting factor for yellow clam density, reaching high values in Monte Hermoso; in fact, in some places with flat beach morphology and fine sand they were highly abundant. Places with rocky outcrops do not offer suitable conditions for the settlement of a dense population of Mesodesma mactroides. The rest of the beach seems to be habitable for clams, their spatial heterogeneity not having been explained by the measured variables since, although PCA demonstrated an E-W physical gradient, clam density was not in correlation with it.

It is worth noting the special condition of the areas near the piers (transect 9 and 11) which, in spite of being different in sand composition and beach morphology, showed the maximum clam densities. This suggests that the unusual concentration of clams is related to some other factors associated to the piers. Possibly the columns supporting the piers modify the local hydrodynamic conditions, accumulation of organic matter or some other unnoticed factors.

Shell length showing a clear E-W gradient was significantly correlated with axis 1 of PCA. The minimum shell size was obtained in the western part of the studied area probably because of the thinness of the sand layer covering the rocky substrate. The small size in front of Monte Hermoso downtown was not related to crowding effects within the clam population because, even though clam density was maximum near the piers (transect 9 and 11), correlation between density and shell size was not significant. Digging sand and extracting clams is prohibited in Monte Hermoso. Since strict control is accomplished in the main touristic area, an argument of overexploitation of the largest clams by tourists, as stated by Olivier \& Penchaszadeh (1968) does not stand in this case; if some illegal clam extraction occurred in the area, it would affect the zone farthest from the piers, where larger clams are however abundant.

Size variations may also derive from differences in recruitment intensity at different points of the beach. There is a very slight possibility that settlement of recruits have failed on the eastern part of the sampling area, in which case lower sizes in the western zone would represent younger clams. However, such stochastic events hardly ever produce a regular pattern along a bed $20 \mathrm{~km}$ long.

Our sampling did not allow us to discriminate between two other possible causes, i.e., differences in growth rates and effects of tourist usage of the beach. Regrettably, the sudden mortality of November 1995 prevented us from continuing with the sampling of this population to test such hypotheses.

It seems realistic that the tendency to reduce shell size towards the west actually illustrates the combination of the effects of removal of the dunes, presence of buildings and vehicles, and increasing tourism pressures, i.e. trampling, dirtying of the sand, etc. Human non-extractive activities in Monte Hermoso do not seem to affect population density but 
mean shell size, probably by the reduction of growth rates.

Mesodesma mactroides migrates in spring from its overwintering position to the upper intertidal fringe (Coscarón, 1959; Defeo et al., 1986). According to Coscarón (1959) and Olivier et al. (1971), almost all the population of $M$. mactroides of Buenos Aires coasts is below the low tide level during winter; only a small proportion of large-sized clams overwinter in the intertidal zone. Defeo et al. (1986), after sampling the intertidal zone in winter, in Barra del Chuy (Uruguay) concluded instead that the winter fraction remaining in the intertidal sands included individuals of all sizes, even when they showed a stratification pattern where the largest clams are located closer to the low tide line; their results also suggested that the winter population in the intertidal zone was more abundant than expected from the previous literature. However, an estimation of the whole population size was not known, because the subtidal fraction was not sampled.

Abundance values found in winter 1995 at Monte Hermoso sandy beach were high, with more than 47 million clams overwintering in the intertidal fringe. During the mass mortality that completely decimated the yellow clam population of Monte Hermoso in November 1995, we estimated the number of dead individuals was nearly 63 million (Fiori \& Cazzaniga, 1999). Since no living clams were found in that beach during the next two years, we conclude that this figure represented the total population three months after the winter assessment here described. We do not have an estimative figure of mortality between August and November 1995, but it is reasonable to think that the winter population was somewhat higher than the population found in November, when the reproductive season had not peaked yet. Consequently, the 47 million clams overwintering in the intertidal fringe represented a major part of the total population, $75 \%$ being the upper bound- which is probably an overestimation. Therefore, this result contradicts the prediction that bulk population remains in the infralittoral during winter.

\section{ACKNOWLEDGMENTS}

Sandra Marcela Fiori is a fellow of the "Consejo Nacional de Investigaciones Científicas y Técnicas" (CONICET), Nestor J. Cazzaniga and Alejandra L. Estebenet are members of the Scientific Research Career of C.I.C. ("Comisión de Investigaciones Científicas de la Provincia de Buenos Aires") and CONICET, respectively. This paper was partially funded by "Centro de Zoología Aplicada de la Universidad Nacional de Córdoba", C.I.C. and the "Universidad Nacional del Sur". Sincere thanks are due to Lic. Gabriela S. Rozas Dennis and Lea
Cazzaniga for her critical reading and language revision.

\section{REFERENCES}

Bastida, R.; Roux, A.; Bremec, C.; Gerpe, M. \& Sorensen, M. 1991. Estructura poblacional de la almeja amarilla (Mesodesma mactroides) durante el verano de 1989 en la provincia de Buenos Aires, Argentina. Frente Marítimo, 9A:83-92.

Brazeiro, A. \& Defeo, O. 1996. Macroinfauna zonation in microtidal sandy beaches: is it possible to identify patterns in such variable environments. Estuar. coast. Shelf. Sci., 42:523-536.

Caló, J. E.; Fernández, J. E. \& Aldacour, H. E. 1995. Caracterización ambiental de la playa de Pehuén-Có en base a procesos oceanográficos y atmosféricos. Su importancia en el manejo costero. In: Cantú, M. P. ed. $1^{\mathrm{a}}$ Reunion Nacional de Geologia Ambiental y Ordenación del Territorio. Rio Cuarto. Universidad Nacional de Rio Cuarto, p.223-236.

Coscarón, S. 1959. La almeja amarilla (Mesodesma (T.) mactroides Deshayes) de la costa de la provincia de Buenos Aires. Agro Publ. Tec., 1:1-66.

Defeo, O.; Layerle, C. \& Masello, A. 1986. Spatial and temporal structure of the yellow clam Mesodesma mactroides population in Barra del Chuy beach (Uruguay) and its relevance for fishery management. Medio Ambiente, 8:48-57.

Defeo, O.; Jaramillo, E. \& Lyonet, A. 1992. Community structure and intertidal zonation of the macroinfauna on the atlantic coast of Uruguay. J. Coast. Res., 8(4):830839.

Fiori, S. M. \& Cazzaniga, N. J. 1999. Mass mortality of the yellow clam, Mesodesma mactroides (Bivalvia: Mactracea) in Monte Hermoso, Argentina. Biol. Conserv., 89:305-309.

Folk, R. L. \& Ward, W. C. 1957. Brazos River bar: a study in the significance of grain size parameters. J. sedim. Petrol. 27:3-27.

IUCN, 1994. Red List Categories. IUCN Species Survival Commission. Gland, IUCN Council. $21 \mathrm{p}$.

McLachlan, A.; Ddugan, J. E.; Defeo, O.; Ansell, A. D. D.; Hubbard, D. M.; Jaramillo, E. \& Penchazsadeh, P. E. 1996. Beach clam fisheries. Oceanogr. mar. Biol. a. Rev., 34:163-232.

Olivier, S. R. \& Penchaszadeh, P. E. 1968. Efectivos de la almeja amarilla (Mesodesma mactroides) en las costas de la provincia de Buenos Aires y pautas para su explotación racional. Proy. Desarr. Pesq. FAO, Ser. Inf. Técn., 8:1-10.

Olivier, S. R.; Capezzani, D. A. A.; Carreto, J. I.; Christiansen, H. E.; Moreno, V. J.; Aizpun de Moreno, J. E. \& Penchaszadeh, P. E. 1971. Estructura de la comunidad, dinámica de la población y biología de la almeja amarilla (Mesodesma mactroides Desh. 1854) en Mar Azul (Pdo. de Gral Madariaga, Bs. As., Argentina). Proy. Desarr. Pesq. FAO, Ser. Inf. Técn., 27:1-90.

Piccolo, M. C.; Varela, P. E.; Cornago, G.; Gelós, O. \& Mercapídez, E. 1987. Estadísticas climatológicas de Monte Hermoso período 1981-1985. Internal Report, Instituto Argentino de Oceanografía, Bahía Blanca. 38 p. (unpubl.) 
Rapson, A. M. 1952. The toheroa, Amphidesma ventricosum Gray (Eulamellibranchiata), development and growth. Aust. J. mar. Freshwat. Res., 3:170-198.

Rapson, A. M. 1954. Feeding and control of toheroa (Amphidesma ventricosum Gray) (Eulamellibranchiata) populations in New Zealand. Aust. J. Mar. Freshwat. Res., 5:486-512.

Servicio de Hidrografía Naval. 1995. Tablas de marea. Buenos Aires, Departamento de Artes Gráficas del S.H.N.

(Manuscript received 27 June 2001; revised 27 August 2002; accepted 29 August 2003) 